\title{
V. V. BELETSKY is an OUTSTANDING MECHANICAL SCIENTIST, ONE of the CLASSICS of SPACE FLIGHT MECHANICS (For the 90th birthday)
}

\author{
G.K. BOROVIN*, Yu.F. GOLUBEV, A.V. GRUSHEVSKII, A.G. TUCHIN \\ Keldysh Institute of Applied Mathematics, Russian Academy of Sciences, Moscow, Russia \\ *Corresponding author: E-mail: borovin@keldysh.ru
}

DOI: $10.20948 /$ mathmontis-2020-47-15

Summary. The article briefly presents the life and scientific activities of an outstanding mechanical scientist, a major scientist, corresponding member of the RAS, honored professor of Lomonosov Moscow State University Vladimir Vasilyevich Beletsky. He is rightly considered one of the founding fathers of the Soviet and Russian school of space flight dynamics in the theory of rotational movements of artificial and natural celestial bodies.

\section{INTRODUCTION}

In 2017, Vladimir Beletsky (Fig.1), an outstanding scientist and unsurpassed teacher, the corresponding member of the RAS, honored Professor of Moscow state University, passed away. He is rightly considered one of the founding fathers of the Soviet and Russian school of space flight dynamics in the field of the theory of rotational movements of artificial and natural celestial bodies.

Vladimir Vasilyevich was born on may 2, 1930 in Irkutsk. He spent his childhood in this city and in the villages on the banks of the Angara and lake Baikal. At the age of 12, he lost his hearing after a severe form of meningitis. In the postwar years, the family moved to Smolensk, where Bielecki graduated from the 7th high school with a gold medal. In 1949, he entered the mechanics and mathematics faculty of Moscow state University. In 1954 he graduated with honors from the faculty of mechanics and mathematics of Lomonosov Moscow State University. In the same year, V.V. Beletsky was assigned to work in the Department of Applied Mathematics of the Steklov Mathematical Institute of the USSR AS USSR, created by M.V. Keldysh (now the Keldysh Institute of Applied Mathematics of RAS). This determined his scientific destiny as one of the galaxy of brilliant scientists representatives of the world-recognized school of space flight dynamics, founded by M.V. Keldysh and D.E. Okhotsimsky. In his book "Theoretical mechanics and modern technology" A.A. Kosmodemyansky wrote: "I Think that for some well-known nowadays scientists interest in certain problems of modern mechanics arose as a result of work in scientific circles and seminars of the mechanics and mathematics faculty of Moscow State University. I can name, for example, the following comrades: corresponding members of the USSR Academy of Sciences D.E. Okhotsimsky and T.M. Eneev, doctors of physicalmathematics sciences V.A. Egorov, V.V. Beletsky, V.A. Sarychev...".

Here is how Vladimir Vasilyevich himself wrote about that time: "I felt that I was in the midst of the brewing events in space exploration and that these events are not least maturing

2010 Mathematics Subject Classification: 37Q05, 70Q05, 70M20, 70F15.

Key words and Phrases: spacecraft, space vehicle, orbiter, artificial earth satellite, artificial moon satellite, artificial martian satellite, gravity assist maneuver, quasi-synchronous orbit. 
thanks to the authoritative, businesslike and purposeful activity of M.V. Keldysh. He defined the style of research direction of the dynamics of space flight and in General the scientific program of space research. This was done by M.V. Keldysh at all levels, up to the state. After all, he was Chairman of the Interdepartmental Commission on space research, and then President of the USSR Academy of Sciences. Later E.L. Akim, A.K. Platonov came to our team, and in 1957 M.L. Lidov was appeared". Characteristic of all his work was the practical direction of research. Most of the results of spacecraft orbit design were implemented in specific missions. Perhaps for this reason, the direction in which the employees of the Keldysh - Okhotsmskiy school acted was called as the "applied celestial mechanics".

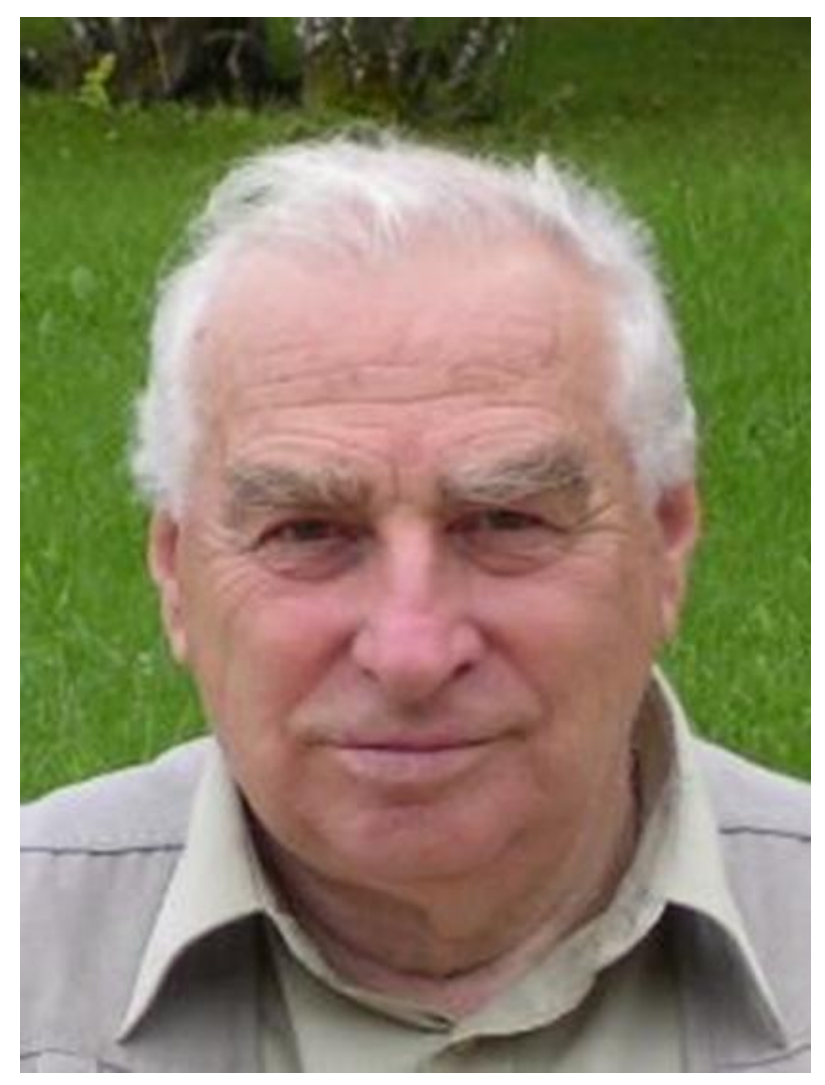

Fig. 1. V.V. Beletsky (02.05.1930-20.07.2017)

Academician D.E. Okhotsimsky wrote about that time: "When in 1953 the Department of applied mathematics of Steklov Moscow Institute Academy Sciences USSR was organized, Mstislav Vsevolodovich offered me to go to the Institute together with the team as the head of the Department. Research on our subject has always been carried out here; first, it was aimed at the development of missile technology, and then, when the air blew the possibility of space launches, we joined in these cases from the very beginning. In 1954, when it became clear that the time of the space age was approaching, she was already knocking at the door, Mstislav Vsevolodovich convened a meeting of scientists and leaders of missile technology. Apparently, as a result of the discussion at this meeting with academician P.L. Kapitsa, Dmitry Evgenievich had the idea of passive gravitational stabilization of artificial earth satellites, i.e. orientation of satellites at the expense of natural forces without any fuel costs 
for orientation control. The fifties years - the years of preparation and implementation of the breakthrough into space - were years of unprecedented takeoff initiated and led by M.V. Keldysh research in the Department of D.E. Okhotsimsky.

\section{SCIENTIFIC ACHIEVEMENTS}

The first researches of V. V. Beletsky became known and recognized by specialists. Speaking on September 14, 1956 at a meeting of the Presidium of the USSR Academy of Sciences, M. V. Keldysh in his report, talking about the stability of the relative equilibrium of the satellite in orbit, said: "... This interesting problem of solid mechanics was solved by a very young employee V. V. Beletsky in the Department of applied mathematics". The results of these studies are summarized in the monograph of 1965, which, being translated into English, and is now a Handbook of specialists.

In the introduction to his monograph V.V. Beletsky indicates that the theory of motion of celestial bodies near the mass center in classical mechanics has developed with respect to specific bodies (Earth, Moon) and therefore used a number of simplifications. In this case, the influence of gravitational moments was mainly considered. The problem of the rotational motion of artificial space objects is much more complex, because "due to the arbitrariness of the shape and mass distribution of the object, the arbitrariness of the initial data, the many factors affecting the movement. In addition to the gravitational moments should take into account more aerodynamic and electromagnetic moments.

V.V. Beletsky practically opened a new branch of the celestial mechanics, simplifying the classical formulation of problems and received as a result of such simplification the main "scrolls" for the mechanics of rotational motion of satellites. On successful examples, he showed how they should be used, came up with the number of interesting problems outside these schemes, solved for the first time standard problems in the new situation. In this sense, Vladimir Beletsky has being brilliantly solved a number of such problems, and become the father-founder for a whole area of such problems solving, giving the scientific community the tools for such solving.

The main results of this cycle of work are as follows. A theorem on the stability conditions of the relative equilibrium of a satellite in a gravitational field is proved. The theory of oscillations of a satellite in an elliptical orbit under the action of the gravitational moment was developed. The problems has been formulated and the theory of the evolution of satellite rotation under the influence of disturbing moments caused by the gravity gradient, the influence of the Earth's magnetic field, atmosphere and light pressure forces has been developed. This theory has been applied to describe the motion of a number of the particular artificial satellites.

V.V. Beletsky was the first who posed and considered the problem of the dynamics of the orbital tethered bodies as a system with release from coupling.

In the same years, V.V. Beletsky for the first time in the world has been setting the general task of determining the actual orientation of the satellite and clarifying the parameters of the perturbing acting moments based on the results of processing the measurements of the orientation sensors installed on Board. He developed and applied an effective method of solving this problem (the third Soviet satellite, the "Proton" satellite, the "Electron" satellites). This approach has been successfully used today. 
Since the early 1970s, V.V. Beletsky has conducted a series of studies of nonlinear problems of the dynamics of rotational motion of artificial satellites and planets, taking into account the existing resonances in their orbital and rotational motion, as well as the effect of energy dissipation (tidal effect) on the formation of a modern picture of the rotation of planets, taking into account the probability of capture in existing resonances [11]. The resonance theory of "generalized Cassini's laws" of planetary rotation was developed by him, which gives a rigorous justification of the empirical Cassini's laws for the moon's rotation (1693).

The main results of Beletsky's scientific activity also include deservedly the theory of tidal evolution of the rotational motion of celestial bodies; the solution of the optimal problems of spacecraft' flights with low-thrust engines; the formulation and analysis of problems of the orbital tether systems dynamics; the construction of models and the study of the of bipedal devices dynamics.

\section{RESULTS}

Here is how briefly V.V. Beletsky presented his main scientific achievements, with links to his own anthology.

1. A theorem on the stability conditions of the relative equilibrium of a satellite in a gravitational field is proved [1], [2]. This result is used in the theory and practice of the passive gravitational stabilization of artificial satellites.

2. The theory of oscillations of a satellite at the elliptical orbit in the gravitational field is developed [1], [2], [3], [4].

3. The problem is posed and the theory of evolution of satellite rotation under the influence of disturbing moments of forces (gravitational, magnetic, aerodynamic, light pressure) [5],[2], the moment of tidal forces [11] is developed.

4. The problem of determining the actual orientation of satellites and the acting moments by on-Board measurements is posed and solved [6], [2], [7].

5. The theory of orbital tether system motion and motion randomization is formulated and developed [8], [9], [10].

6. A resonant theory of generalized "Cassini's laws of rotation" of the natural and artificial celestial bodies has been created [12], [13]. This theory, in particular, justifies the empirical laws of J.D. Cassini, established more than 300 years ago (1693).

Vladimir V. Beletsky, as a chief scientific officer of the KIAM of RAS, was the Member of his Scientific Council, also has been a Member of the specialized dissertation councils of KIAM RAS and mechanics and mathematics faculty of Lomonosov Moscow State University, a Member of the Russian National Committee on Theoretical and Applied Mechanics (1976). In 1997 he was awarded the title corresponding member of RAS. He was a Full member of the International Academy of Astronautics (1992) and a Full member of the Russian Academy of cosmonautics (1994), was a Member of the editorial Board of the journal "Regular and chaotic dynamics". V.V. Beletsky prepared 26 candidates and 5 Doctors of Sciences.

Beletsky's scientific achievements are highly appreciated in Russia and abroad. He was awarded Honored Professor of Lomonosov MSU (2002), and laureate of A. von Humboldt 
prize (Germany). He honored the F.A. Tsander prize of RAS. The minor planet No. 14790 (discovered July 30, 1970) has been named after V.V. Beletsky "Beletskij” (Fig.2).

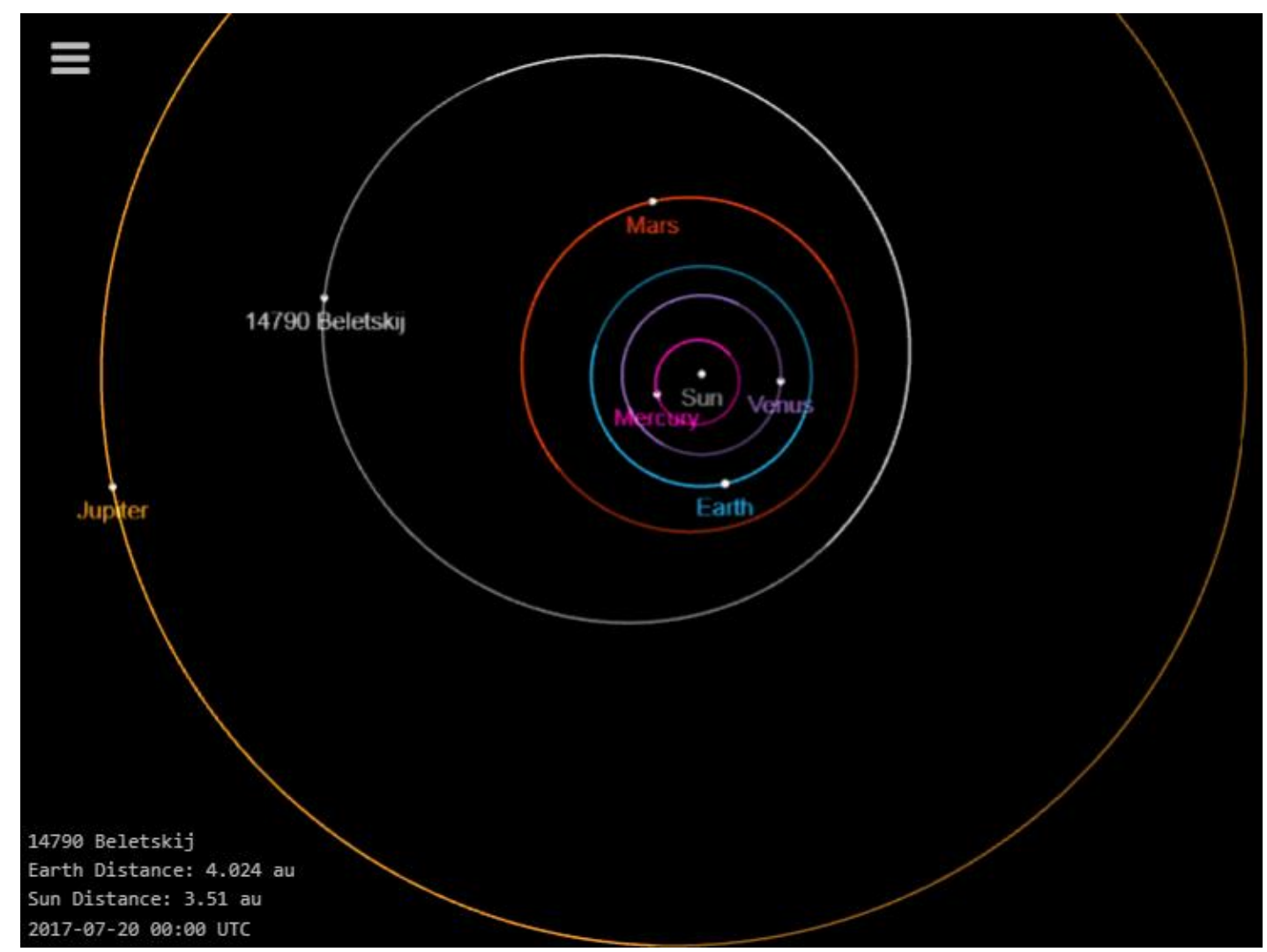

Fig. 2. Small planet № 14790 (opened July 30, 1970), named after V.V. Beletsky

Summarizing, it can be argued that V.V. Beletsky practically opened a new the scientific school and the branch of the celestial mechanics, simplifying the classical formulation of problems and developed in such simplification main "science scrolls" to describe the mechanics of the rotational motion of a satellites and planets.

\section{REFERENCES}

[1] V.V. Beletsky, "O libratcii sputneyka", Iskusstvennye sputneyki Zemli. M.: Izd-vo AN SSSR, 3, 13-31, (1959).

[2] V.V. Beletsky, Dvizhenie iskusstvennogo sputneyka otnositelno centra mass, M.: Nauka, (1965).

[3] V.A. Zlatoustov, D.E. Okhotsimsky, V.F. Sarychev, A.P. Torzhevsky, "Periodicheskie resheniya $\mathrm{v}$ zadachah o ploskih kolebaniyah sputneyka na ellipticheskoy orbite", Kosmicheskie issledovaniya,2(5), 658-666 (1964).

[4] A.D. Bryuno, "Semeistvo periodicheskih reshenii uravneniya Beletskogo", Kosmicheskie issledovaniya, 40(3), 295-316 (2002).

[5] V.V. Beletsky, "Dvizhenie iskusstvennogo sputneyka otnositelno centra mass", Kosmicheskie issledovaniya, 1, 25-43 (1957).

[6] V.V. Beletsky, Yu.V. Zonov, "Vrashenie i orientaciya tretego sovetskogo sputneyka", Iskusstvennye sputneyki Zemli. M.: Izd-vo AN SSSR, 7, 32-55, (1961). 
[7] V.V. Beletsky, V.V. Golubkov, E.A. Stepanova, I.G. Hatckevich, "Rezultaty opredeleniya orientacii sputnika "Proton-2" i opisanie ego dvizheniya otnositelno centra mass", Kosmicheskie issledovaniya,7(4), 522-533 (1969).

[8] V.V. Beletsky, E.T. Novikova, "Ob otnositelnom dvizhenii cvyazki dvuh tel na orbite", Kosmicheskie issledovaniya,7(3), 377-384 (1969).

[9] V.V. Beletsky, E.M. Levin, Dinamika kosmicheskih trosovyh system, M.: Nauka, (1990).

[10] V.V. Beletsky, D.V. Pankov, "Connected bodies in the orbit as a dynamic billiard", Regular and chaotic dynamics, 1, 87-103 (1996).

[11] V.V. Beletsky, A.V. Grushevskii, "Model formirovaniya vrashatelnyh dvizhenii nebesnyh tel s ogranicheniyami na poryadok rezonansov", Astronomicheskii vestnik, 24(2), 140-147 (1990).

[12] V.V. Beletsky, "Resonance rotation of celestial bodies and Cassini's laws", Celest. Mech., 6(3), 356-378 (1972).

[13] V.V. Beletsky, Dvizhenie sputneyka otnositelno centra mass v gravitatcionnom pole, M.: Izd. MGU, (1975)

Received November 15, 2019 


\title{
БЕЛЕЦКИЙ В.В. - ВЫДАЮЩИЙСЯ УЧЁНЫЙ-МЕХАНИК, ОДИН ИЗ КЛАССИКОВ МЕХАНИКИ КОСМИЧЕСКОГО ПОЛЁТА (К 90-летию со дня рождения)
}

\author{
Г.К. БОРОВИН*, Ю.Ф. ГОЛУБЕВ, А.В. ГРУШЕВСКИЙ, А.Г. ТУЧИН \\ Институт прикладной математики им. М.В. Келдыша РАН. Москва, Россия \\ *Ответственный автор: E-mail: borovin@keldysh.ru
}

DOI: $10.20948 /$ mathmontis-2020-47-15

Ключевые слова: космический аппарат, искусственный спутник Земли, искусственный спутник Луны, искусственный спутник Марса, планета Венера, гравитационный манёвр, гравитационное поле

\begin{abstract}
Аннотация. В статье кратко представлена жизнь и научная деятельность выдающегося ученого-механика, крупного ученого, члена-корреспондента РАН, заслуженного профессора МГУ имени М.В.Ломоносова Владимира Васильевича Белецкого. Он по праву считается одним из основателей советской и российской школы динамики космических полетов в теории вращательных движений искусственных и естественных небесных тел.
\end{abstract}

\section{1 ВВЕДЕНИЕ}

Владимир Васильевич Белецкий (Рис.1.) родился 2 мая 1930 года в городе Иркутске. Детство его прошло в этом городе и в деревнях на берегах Ангары и Байкала. В 12 летнем возрасте потерял слух после перенесённой им тяжёлой формы менингита. В послевоенные годы семья переехала в Смоленск, где Белецкий закончил 7-ю среднюю школу с золотой медалью.

В 1949 году он поступил на механико-математический факультет МГУ. В 1954 г. он окончил с отличием механико-математический факультет МГУ им. М.В. Ломоносова. В том же году В.В. Белецкий был распределен на работу в Отделение прикладной математики МИАН СССР, только что созданное М.В. Келдышем (теперь Институт прикладной математики им. М.В. Келдыша РАН). Это определило его научную судьбу как одного из плеяды блестящих ученых - представителей всемирно признанной школы динамики космического полета, основанной М.В. Келдышем и Д.Е. Охоцимским. В своей книге «Теоретическая механика и современная техника» А.А. Космодемьянский писал: «Думаю, что для некоторых известных в наши дни ученых интерес к определенным проблемам современной механики зародился в результате работы в научных кружках и семинарах механико-математического факультета МГУ. Я могу назвать, например, следующих товарищей: члены-корреспонденты АН СССР Д.Е. Охоцимский и Т.М. Энеев, доктора физ.-мат. наук В.А. Егоров, В.В. Белецкий, В.А. Сарычев...».

2010 Mathematics Subject Classification: 37Q05, 70Q05, 70M20, 70F15.

Key words and Phrases: spacecraft, space vehicle, orbiter, artificial earth satellite, artificial moon satellite, artificial martian satellite, gravity assist maneuver, quasi-synchronous orbit 


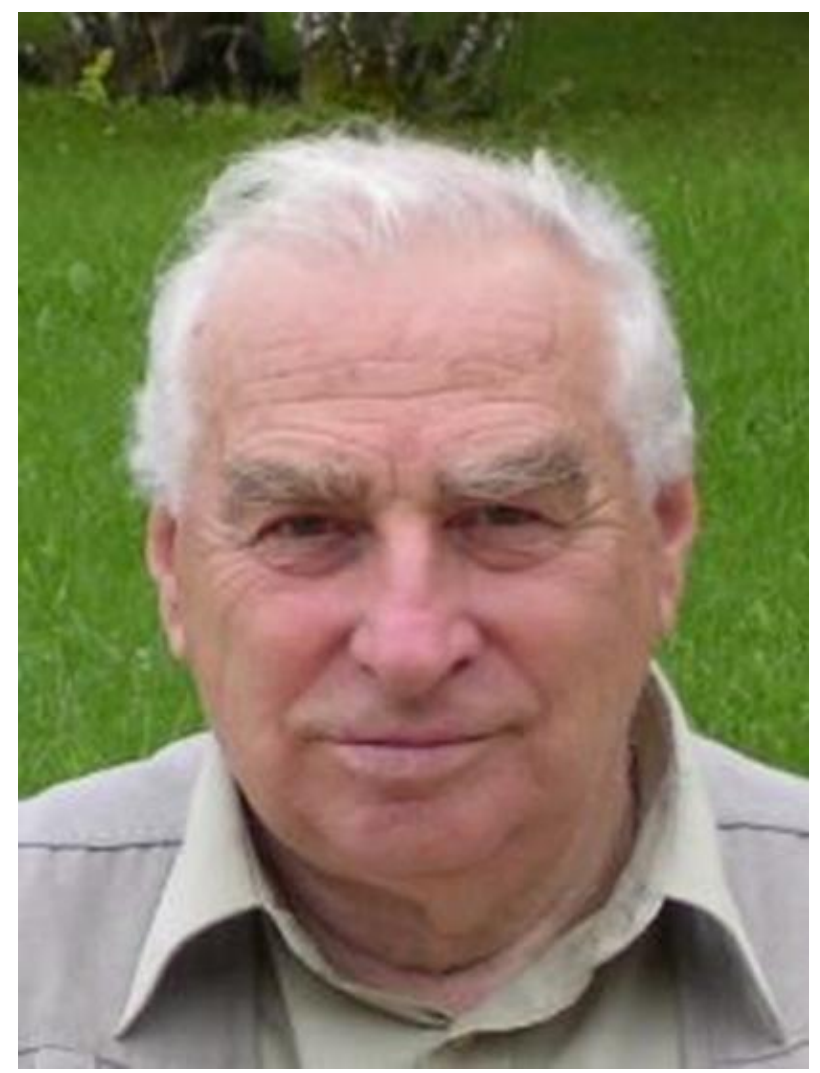

Рис. 1. В.В.Белецкий (02.05.1930-20.07.2017)

Вот как сам Владимир Васильевич писал о том времени: «Я почувствовал, что попал в самую гущу назревающих событий в исследовании космоса и что эти события не в последнюю очередь зреют благодаря авторитетной, деловитой и целеустремленной деятельности М.В. Келдыша. Он определял стиль направление исследований динамики космического полета и вообще научной программы исследования космического пространства. Это делалось М.В. Келдышем на всех уровнях, вплоть до государственного. Ведь он был председателем Межведомственной комиссии по исследованию космоса, а потом и президентом Академии наук СССР. Несколько позже в наш коллектив пришли Э.Л. Аким, А.К. Платонов, а в 1957 г. появился М.Л. Лидов». Характерным для всего его творчества была практическая направленность исследований. Большая часть результатов по проектированию орбит космических аппаратов была реализована в конкретных полетах. Может быть, по этой причине направление, на котором действовали сотрудники школы Келдыша - Охоцимского, получило название "прикладная небесная механика".

Академик Д.Е. Охоцимский писал о том времени: «Когда в 1953 г. организовывалось Отделение прикладной математики, Мстислав Всеволодович предложил мне перейти в ОПМ вместе с коллективом в качестве руководителя отдела. Исследования по нашей тематике здесь проводились всегда; сперва они были направлены на развитие ракетной техники, а затем, когда в воздухе повеяло возможностью космических запусков, мы с самого начала подключились к этим делам. В 1954 г., когда уже стало ясным, что 
приближается время космической эры, она уже стучится в дверь, Мстислав Всеволодович созвал совещание ученых и руководителей ракетной техники. Видимо, в результате дискуссии на этом совещании с академиком П.Л. Капицей у Дмитрия Евгеньевича родилась идея пассивной гравитационной стабилизации искусственных спутников Земли, т.е. ориентации спутников за счет природных сил без всяких затрат топлива на управление ориентацией. Пятидесятые годы - годы подготовки и реализации прорыва в космос - были годами невиданного взлета инициированных и руководимых М.В. Келдышем научных исследований в отделе Д.Е. Охоцимского.

\section{2 НАУЧНЫЕ ДОСТИЖЕНИЯ}

Уже первые исследования В.В. Белецкого приобрели известность и признание специалистов. Выступая 14 сентября 1956 г. на заседании президиума Академии наук СССР, М.В. Келдыш в своем докладе, рассказывая об устойчивости относительного равновесия спутника на орбите, заметил: "... Эта интереснейшая задача механики твердого тела была решена совсем еще молодым сотрудником В.В. Белецким в Отделении прикладной математики". Результаты этих исследований подытожены в монографии 1965 г., которая, будучи переведенной на английский язык, и сейчас является настольной книгой специалистов.

Во введении к монографии В.В. Белецкий указывает, что теория движения небесных тел около центра масс в классической механике развивалась применительно к конкретным телам (Земля, Луна) и посему использует ряд упрощений. При этом рассматривалось в основном влияние гравитационных моментов. Задача о вращательном движении искусственных космических объектов гораздо более сложна, поскольку «обусловливается произвольностью формы и распределения масс объекта, произвольностью начальных данных, многочисленностью факторов, влияющих на движение. Кроме гравитационных моментов следует учитывать ещё аэродинамические и электромагнитные моменты.

В.В. Белецкий практически открыл новую отрасль механики, упростив классические постановки задач и получив в результате такого упрощения основные «скрижали» для механики вращательного движения спутников. На удачных примерах он показал, как их надо использовать, придумал ряд интересных задач вне этих схем, впервые решил стандартные задачи в новой ситуации. В этом смысле Владимир Васильевич Белецкий, с блеском решив ряд указанных задач, явился отцом-основателем целого направления по решению подобных задач, дав научному сообществу инструментарий для их решения.

Основные результаты этого цикла работ состоят в следующем. Доказана теорема об условиях устойчивости относительного равновесия спутника в гравитационном поле. Развита теория колебаний спутника на эллиптической орбите под действием момента градиента силы тяжести. Выполнена постановка проблема и разработана теория эволюции вращения спутников под влиянием возмущающих моментов, вызванных градиентом силы тяжести, влиянием магнитного поля Земли, атмосферы и сил светового давления. Эта теория нашла свое применение для описания движения целого ряда конкретных спутников.

В.В. Белецкий впервые поставил и рассмотрел проблему динамики орбитальной "связки тел" как системы с освобождающей связью. 
В эти же годы В.В. Белецкий впервые в мире поставил общую задачу об определении фактической ориентации спутника и уточнения параметров действующих на него возмущающих моментов по результатам обработки измерений датчиков ориентации, установленных на борту. Он разработал и применил эффективную методику решения этой задачи (третий советский спутник, спутник "Протон", спутники "Электрон"). Этот подход успешно используется и в наши дни.

С начала 1970-х годов В.В. Белецкий провел цикл исследований нелинейных проблем динамики вращательного движения искусственных спутников и планет с учетом существующих резонансов в их орбитальном и вращательном движении, а также влияния диссипации энергии (приливной эффект) на формирование современной картины вращения планет с учетом вероятностей захвата в существующие резонансы [11]. Им создана резонансная теория "обобщенных законов Кассини" вращения планет, которая дает строгое обоснование эмпирических законов Кассини вращения Луны (1693).

В.В. Белецкий опубликовал свыше 200 научных работ, в том числе 11 монографий, переиздававшихся в стране и за рубежом. Его работы легко читать, потому что они написаны с любовью к читателю и сочетают в себе строгость анализа и прекрасный стиль изложения.

К числу замечательных научных достижений В.В. Белецкого относится его монография "Очерки о движении космических тел" (второе издание в 1977 г.), переведенная на многие языки. В этой книге, написанной живым и красочным языком, ясно и доступно излагались как классические, так и современные результаты исследований многих учёных (и самого автора) в области небесной механики.

К основным результатам научной деятельности В.В. Белецкого заслуженно также относятся: теория приливных эффектов во вращении и ориентации небесных тел; решение оптимальных задач космических перелетов с двигателями малой тяги; постановка и анализ проблем динамики орбитальных тросовых систем; построение моделей и исследование динамики двуногоходящих устройств.

\section{3 ИТОГИ}

Вот как вкратце сам В.В. Белецкий представлял свои основные научные достижения со ссылками на собственную антологию.

1. Доказана теорема об условиях устойчивости относительного равновесия спутника в гравитационном поле [1], [2]. Этот результат используется в теории и практике систем пассивной гравитационной стабилизации спутников.

2. Развита теория колебаний спутника на эллиптической орбите в гравитационном поле [1], [2], [3],[4].

3. Поставлена проблема и разработана теория эволюции вращения спутников под влиянием возмущающих моментов сил (гравитационных, магнитных, аэродинамических, светового давления) [5],[2], момента приливных сил [11].

4. Поставлена и решена проблема определения по бортовым измерениям фактической ориентации спутников и действующих на него моментов [6], [2], [7].

5. Поставлена и развита теория движения орбитальной тросовой системы и хаотизации движения [8], [9], [10]. 
6. Создана резонансная теория обобщенных законов Кассини «вращения» естественных и искусственных небесных тел [12], [13]. Эта теория, в частности, обосновывает эмпирические законы Дж. Д. Кассини, установленные более 300 лет тому назад (в 1693г.).

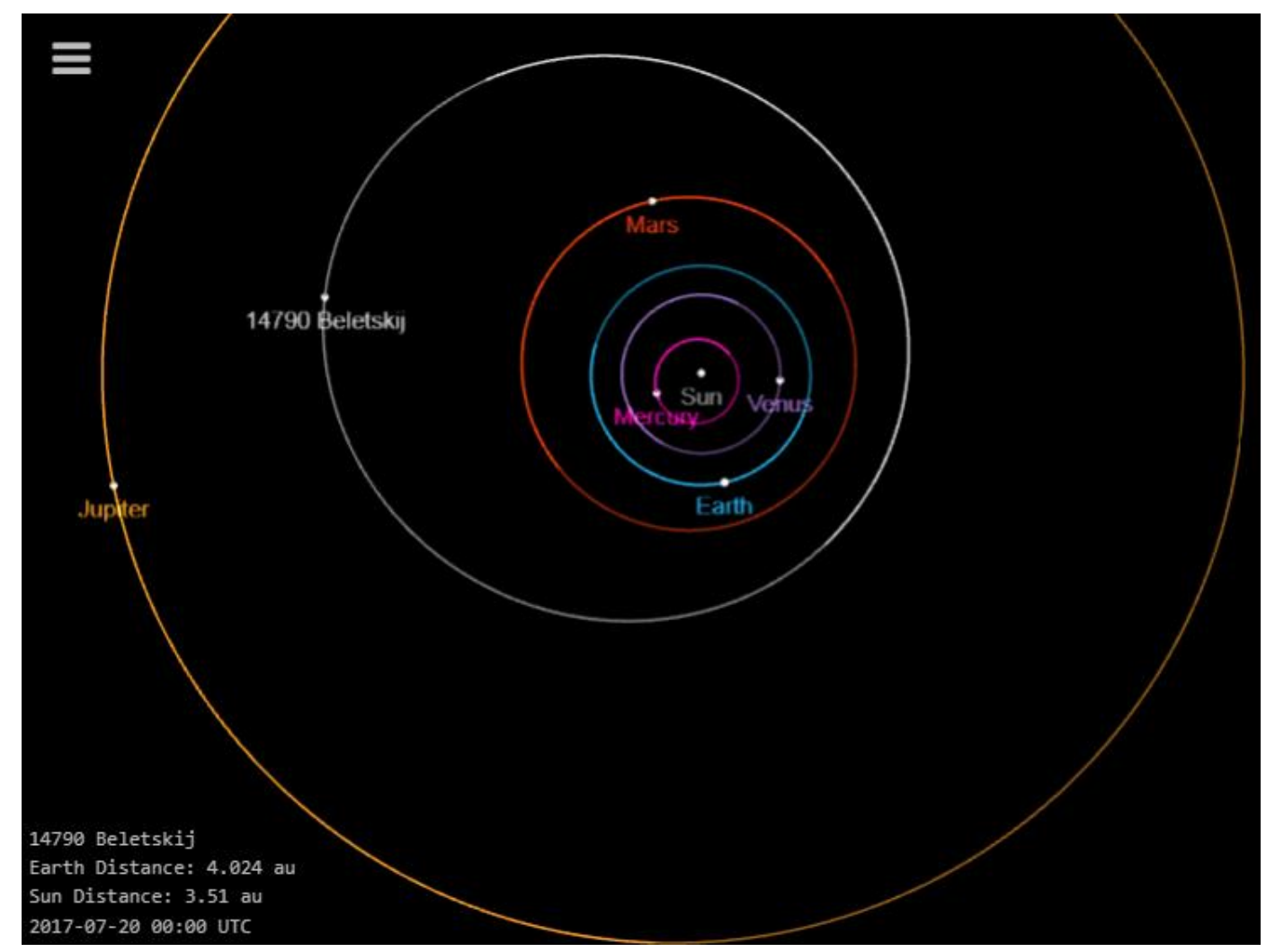

Рис. 2. Малая планета № 14790 (открыта 30 июля 1970 г.), названная именем В.В. Белецкого

Владимир Васильевич Белецкий, будучи главным научным сотрудником ИПМ им. М.В. Келдыша РАН, состоял Членом его Ученого совета, являлся также Членом специализированных диссертационных советов ИПМ им. М.В.Келдыша РАН и механико-математического факультета МГУ им. М.В. Ломоносова, Членом Российского национального комитета по теоретической и прикладной механике (1976). Он был избран Членом-корреспондентом РАН (1997), являлся Действительным членом Международной академии астронавтики (1992) и Действительным членом Российской академии космонавтики (1994), состоял Членом редколлегии журнала "Регулярная и хаотическая динамика".

Научные достижения В.В. Белецкого высоко оценены в России и за рубежом. Он был удостоен звания Заслуженный профессор МГУ (2002), стал лауреатом премии А. фон Гумбольдта (Германия), лауреат премии РАН им. Ф.А. Цандера. Малая планета № 14790 (открыта 30 июля 1970 г.), названа именем В.В. Белецкого "Beletskij” (рис. 1).

Резюмируя, можно утверждать, что В.В. Белецкий практически открыл новую отрасль механики, упростив классические постановки задач и получив в результате такого упрощения основные «скрижали» для описания механики вращательного движения спутников и планет. 
Это был блистательный учёный и непревзойдённый учитель. Его по праву считают одним из отцов-основателей советской и российской школы динамики космического полёта в области теории вращательных движений искусственных и естественных небесных тел. Владимир Васильевич Белецкий скончался 20 июля 2017 г. Владимир Васильевич похоронен на Троекуровском кладбище в Москве.

\section{REFERENCES}

[1] V.V. Beletsky, "O libratcii sputneyka”, Iskusstvennye sputneyki Zemli. M.: Izd-vo AN SSSR, 3, 13-31, (1959).

[2] V.V. Beletsky, Dvizhenie iskusstvennogo sputneyka otnositelno centra mass, M.: Nauka, (1965).

[3] V.A. Zlatoustov, D.E. Okhotsimsky, V.F. Sarychev, A.P. Torzhevsky, "Periodicheskie resheniya $\mathrm{v}$ zadachah o ploskih kolebaniyah sputneyka na ellipticheskoy orbite", Kosmicheskie issledovaniya,2(5), 658-666 (1964).

[4] A.D. Bryuno, "Semeistvo periodicheskih reshenii uravneniya Beletskogo", Kosmicheskie issledovaniya, 40(3), 295-316 (2002).

[5] V.V. Beletsky, "Dvizhenie iskusstvennogo sputneyka otnositelno centra mass", Kosmicheskie issledovaniya, 1, 25-43 (1957).

[6] V.V. Beletsky, Yu.V. Zonov, "Vrashenie i orientaciya tretego sovetskogo sputneyka", Iskusstvennye sputneyki Zemli. M.: Izd-vo AN SSSR, 7, 32-55, (1961).

[7] V.V. Beletsky, V.V. Golubkov, E.A. Stepanova, I.G. Hatckevich, "Rezultaty opredeleniya orientacii sputnika "Proton-2" i opisanie ego dvizheniya otnositelno centra mass", Kosmicheskie issledovaniya,7(4), 522-533 (1969).

[8] V.V. Beletsky, E.T. Novikova, "Ob otnositelnom dvizhenii cvyazki dvuh tel na orbite", Kosmicheskie issledovaniya,7(3), 377-384 (1969).

[9] V.V. Beletsky, E.M. Levin, Dinamika kosmicheskih trosovyh system, M.: Nauka, (1990).

[10]V.V. Beletsky, D.V. Pankov, "Connected bodies in the orbit as a dynamic billiard", Regular and chaotic dynamics, 1, 87-103 (1996).

[11]V.V. Beletsky, A.V. Grushevskii, "Model formirovaniya vrashatelnyh dvizhenii nebesnyh tel s ogranicheniyami na poryadok rezonansov", Astronomicheskii vestnik, 24(2), 140-147 (1990).

[12] V.V. Beletsky, "Resonance rotation of celestial bodies and Cassini's laws", Celest. Mech., 6(3), 356-378 (1972).

[13]V.V. Beletsky, Dvizhenie sputneyka otnositelno centra mass v gravitatcionnom pole, M.: Izd. MGU, (1975)

Received November 15, 2019 